\title{
Phenotypic variability of fruits and seeds in natural populations of Hymenaea stigonocarpa (Mart. Ex Hayne) ${ }^{1}$
}

\author{
Rodrigo Soares de Castro ${ }^{2}$, Ariany Rosa Gonçalves ${ }^{3}$, \\ Ramilla dos Santos Braga-Ferreira ${ }^{4}$, Mariana Pires de Campos Telles ${ }^{5}$, Lázaro José Chaves ${ }^{2}$
}

\section{ABSTRACT}

Hymenaea stigonocarpa (Mart. Ex Hayne), popularly known as jatobá-do-cerrado, is a fruit tree widely distributed in the Brazilian Savanna, has multiple uses and is a promising genetic resource. This study aimed to physically characterize fruits and seeds of $H$. stigonocarpa, as well as to estimate the phenotypic variability at three hierarchical levels: populations, mother trees within populations, and fruits/seeds within mother trees. Fruits from six mother trees were sampled from each of the 25 natural populations found in the Brazilian Savanna. The morphometric characterization of 742 fruits was carried out by evaluating 10 quantitative traits in fruits and seeds. In addition, comparative analyses were performed between the average values of $H$. stigonocarpa and the botanical variety H. stigonocarpa var. brevipetiolata. Significant phenotypic variations were noticed at all hierarchical levels. A high phenotypic differentiation among the populations was observed for quantitative traits (fruit mass and size, pulp mass and seed mass), being higher when $H$. stigonocarpa var. brevipetiolata was included in the analysis.

KEYWORDS: Brazilian Savanna, genetic pre-breeding, jatobádo-cerrado.

\section{INTRODUCTION}

Cerrado (Brazilian Savanna) is a biome with high biological diversity (Mittermeier et al. 2011) that has evolved due to adaptation to fire (Simon \& Pennington 2012), intrinsic soil characteristics, and climatic and environmental variables (Françoso et al. 2020). Among more than 12 thousand plant species that inhabit the phytophysiognomies of this biome, fruits are predominant genetic resources and have

\section{RESUMO}

Variabilidade fenotípica de frutos e sementes em populações naturais de Hymenaea stigonocarpa (Mart. Ex Hayne)

Hymenaea stigonocarpa (Mart. Ex Hayne), popularmente conhecida como jatobá-do-cerrado, é uma árvore frutífera amplamente distribuída no Cerrado, a qual possui múltiplos usos e é um recurso genético promissor. Objetivou-se caracterizar fisicamente frutos e sementes de $H$. stigonocarpa, bem como estimar a variabilidade fenotípica em três níveis hierárquicos: populações, matrizes dentro de populações e frutos/sementes dentro de matrizes. Frutos de seis matrizes foram amostrados de cada uma das 25 populações naturais encontradas no Cerrado. A caracterização morfométrica de 742 frutos foi realizada avaliando-se 10 caracteres quantitativos em frutos e sementes. Além disso, foram realizadas análises comparativas entre os valores médios de H. stigonocarpa e a variedade botânica $H$. stigonocarpa var. brevipetiolata. Variações fenotípicas significativas ocorreram em todos os níveis hierárquicos. Observou-se alta diferenciação fenotípica entre as populações para caracteres quantitativos (massa e tamanho do fruto, massa da polpa e da semente), a qual foi ainda maior quando H. stigonocarpa var. brevipetiolata foi incluída na análise

PALAVRAS-CHAVE: Cerrado, pré-melhoramento genético, jatobá-do-cerrado.

several applications, especially in the medicinal and food industries (Mendonça et al. 2008).

Plant species with extensive geographical distribution occurring in different biomes are important from the viewpoint of local adaptation and phenotypic plasticity. Therefore, Hymenaea stigonocarpa (Mart. ex Hayne), popularly known as jatobá-do-cerrado, is a good model for evaluating the variability of phenotypic traits, as it occurs mainly in the Cerrado, Caatinga, Pantanal and Amazônia biomes (Pinto et al. 2020).

${ }^{1}$ Received: Jan. 06, 2021. Accepted: Feb. 26, 2021. Published: June 11, 2021. DOI: 10.1590/1983-40632021v5167292.

${ }^{2}$ Universidade Federal de Goiás, Escola de Agronomia, Goiânia, GO, Brasil.

E-mail/ORCID: rcastro005@yahoo.com/0000-0002-7760-7674, lchaves@ufg.br/0000-0002-4678-9014.

${ }^{3}$ Universidade Federal de Goiás, Instituto de Ciências Biológicas, Goiânia, GO, Brasil. E-mail/ORCID: ariany.biol@gmail.com/0000-0001-6887-5362.

${ }^{4}$ Universidade Federal de Goiás, Instituto Nacional de Ciência \& Tecnologia em Ecologia, Evolução e Conservação da Biodiversidade, Goiânia, GO, Brasil.E-mail/ORCID: ramillabraga@gmail.com/0000-0002-1493-8601.

${ }^{5}$ Pontifícia Universidade Católica de Goiás, Goiânia, GO, Brasil. E-mail/ORCID: tellesmpc@gmail.com/0000-0002-9023-0007. 
The use of the genetic resources of $H$. stigonocarpa is limited to extractivism, as its planting systems are still unknown. The farinaceous pulp of this species is used for food preparations and the bark for extracting chemical compounds that have medicinal and industrial use (Almeida et al. 1998, Carvalho 2007). H. stigonocarpa is a tree that can reach a height of approximately $20 \mathrm{~m}$ and is used for reforestation and recovery of degraded areas, because it is highly appreciated by the fauna (Carvalho 2007). The main pollination vectors of its fruits are bats of the Glossophaga genus, which forage for nectar (Gibbs et al. 1999). Its seeds dispersal occurs by zoochory, mainly by mammals and birds (Gibbs et al. 1999, Carvalho 2007).

The morphometric analysis of fruits and seeds provides important information for taxonomic applications, dispersion mechanisms and germination viability (Pereira et al. 2011). The collection of phenotypic data allows the adoption of conservation strategies that consider both the local adaptation and pre-breeding aspects (Boaventura-Novaes et al. 2018b). Thus, for using H. stigonocarpa as a genetic resource, studies are needed to assess its phenotypic variability in various geographical locations, due to its distribution in different biomes.

Recently, population genetic studies have shown that there is a high genetic differentiation among populations of $H$. stigonocarpa that is caused by genetic drift and divergence among the botanical varieties of the species (Braga et al. 2019, Gonçalves et al. 2019). Based on microsatellite markers, the existence of two genetic groups separated by intervarietal genetic divergence and space was verified, and geographically close populations were found to be more genetically similar (Braga et al. 2019). These results suggest an environmental heterogeneity, which may lead to a local adaptation that can be investigated at the phenotypic level (Neale \& Kremer 2011, Alberto et al. 2013).

For H. stigonocarpa, phenotypic plasticity and local adaptation are factors responsible for a leaf variation in the species that is observed even at an individual level (Pestana 2010). Due to this reason, the investigation of the phenotypic variability in quantitative traits of fruits and seeds is important for taxonomic level assessments and for both in situ and ex situ conservation proposals. Such studies are relevant because a large intrapopulation phenotypic variation was found in $H$. stigonocarpa var. stigonocarpa fruits (Pereira et al. 2011), suggesting that more advanced studies may decipher phenotypic variation among populations that are influenced by environmental variables. Thus, this study aimed to evaluate the phenotypic variability observed in fruits and seeds of $H$. stigonocarpa collected from natural populations, in order to seek new biological information of the species and support future genetic breeding and conservation programs aimed at its domestication and sustainable use.

\section{MATERIAL AND METHODS}

Six expeditions were carried out to collect H. stigonocarpa fruits between September and October 2012. The sampling of 25 populations distributed over five states of the Brazilian Savanna with a minimum distance of $100 \mathrm{~km}$ was carried out (Figure 1). In each population, six mother trees were randomly sampled, and at least 10 ripe fruits per mother tree were collected. The collected fruits were packed in meshed bags labeled with the population type and the corresponding mother tree and georeferenced by a GPS receiver. The coordinates of each population and details of the collection have been previously published (Castro 2016).

To evaluate the phenotypic variability of fruits and seeds, a morphometric characterization was performed by randomly sampling five healthy fruits from each mother tree, totaling 750 fruits. However, some fruits from the São Miguel do Araguaia (Goiás state) and Pedro Gomes (Mato Grosso do Sul state) populations were discarded due to pest damage and other phytosanitary problems. Thus, 742 fruits were characterized. The following traits were evaluated: fruit length (FL); fruit width (FW); fruit thickness (FT); fruit mass (FM); number of seeds per fruit (NSF); length-to-width fruit ratio $(\mathrm{LWR}=\mathrm{FL} / \mathrm{FW})$; width-to-thickness fruit ratio $(\mathrm{WTR}=\mathrm{FW} / \mathrm{FT})$; pulp mass $\{(\mathrm{PM})=[\mathrm{FM}-(\mathrm{SM}+\mathrm{EM})]$, where $\mathrm{SM}$ is the seed mass and EM the fruit peel mass $\}$; pulp yield $[(\mathrm{YIELD})=(\mathrm{PM} / \mathrm{FM}) * 100]$; and mass of one seed $[(\mathrm{M} 1 \mathrm{~S})=\mathrm{SM} / \mathrm{NSF}]$. The mass measurements, expressed in grams, were obtained using a semianalytical digital scale (accuracy of $0.1 \mathrm{~g}$ ). The size traits, expressed in millimeters, were measured with a digital caliper (precision of $0.1 \mathrm{~mm}$ ).

The quantitative variables were subjected to descriptive statistical analysis followed by analysis of variance (Anova), in a random hierarchical 

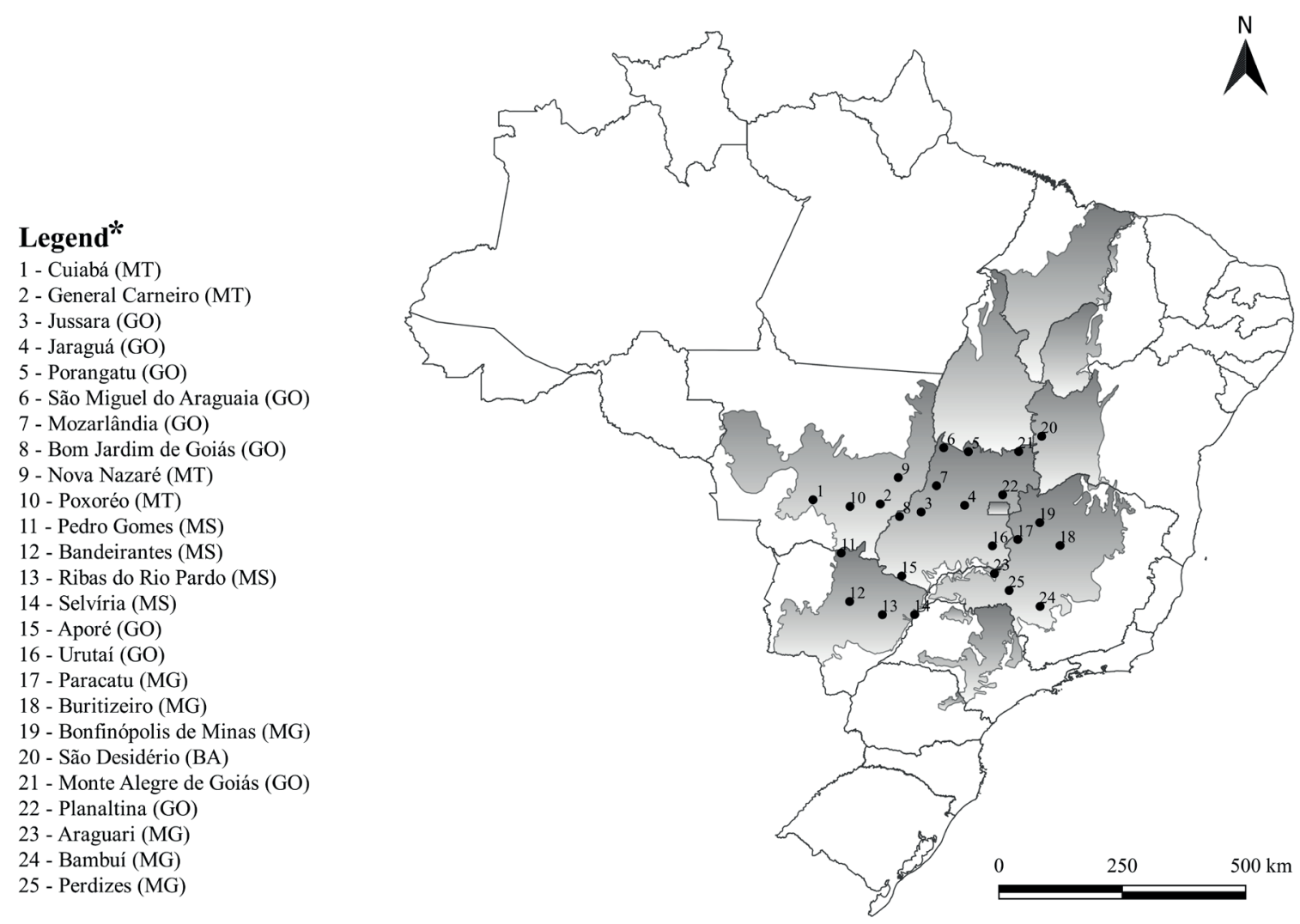

Figure 1. Location of 25 populations of Hymenaea stigonocarpa sampled for morphometric characterization of fruits and seeds in the Brazilian Savanna. * BA: Bahia state; GO: Goiás state; MG: Minas Gerais state; MS: Mato Grosso do Sul state; MT: Mato Grosso state.

model that took into consideration the effects of populations, mother trees within populations and fruits (or seeds) of mother trees. The model components of variance were obtained from the expected mean squares of Anova using the method of moments. From these components, the proportion of the total phenotypic variation was estimated, corresponding to the effects of populations $\left(P_{S}\right)$, mother trees within populations $\left(P_{M / S}\right)$ and fruits (or seeds) of mother trees within populations $\left(P_{N / M}\right)$. In addition, the $P_{S T}$ parameter was estimated, which is the measure of the phenotypic divergence observed among the populations of $H$. stigonocarpa, using the following expression:

$$
\hat{\mathrm{P}}_{\mathrm{ST}}=\left(\hat{\sigma}_{\mathrm{p}}^{2}\right) /\left(\hat{\sigma}_{\mathrm{p}}^{2}+2 \hat{\sigma}_{\mathrm{m}}^{2}\right),
$$

where $\hat{\sigma}_{\mathrm{p}}^{2}$ is the component of the phenotypic variance among the populations and $\hat{\sigma}_{\mathrm{m}}^{2}$ the component of phenotypic variance among the mother plants within the populations.

The phenotypic correlation coefficients between fruit and seed traits were estimated using the average value of each mother plant. Additionally, average values for fruits and seeds of populations of the botanical variety $H$. stigonocarpa var. brevipetiolata were calculated. These averages were compared with those of other populations, which contained other varieties, using the Student's $t$-test.

\section{RESULTS AND DISCUSSION}

The traits evaluated for fruits and seeds of H. stigonocarpa showed a higher phenotypic variation, when compared with other sampled populations (Table 1). Based on the coefficients of variation, the largest variations were observed for number of seeds per fruit, pulp mass and fruit mass (Table 1). These data are similar to those of a biometric study of fruits and seeds of five populations of $H$. stigonocarpa located in the Minas Gerais state (Botelho 1993). In that study, the fruit mass and number of seeds per fruit also showed the highest coefficients of variation, except for pulp mass, which was not evaluated (Botelho 1993). 
Table 1. Average, minimum and maximum values and phenotypic coefficients of variation for physical traits of fruits and seeds of 25 populations of Hymenaea stigonocarpa from the Brazilian Savanna.

\begin{tabular}{|c|c|c|c|c|c|c|c|c|c|c|}
\hline Population & FL & FW & FT & LWR & WTR & FM & PM & YIELD & $\mathrm{NSF}$ & M1S \\
\hline 1 & 105.06 & 44.38 & 33.11 & 2.40 & 1.36 & 41.52 & 7.27 & 17.06 & 3.30 & 2.34 \\
\hline 2 & 111.74 & 41.12 & 34.68 & 2.75 & 1.19 & 36.26 & 8.78 & 22.64 & 4.87 & 1.68 \\
\hline 3 & 120.41 & 40.48 & 33.71 & 2.98 & 1.20 & 36.95 & 6.31 & 16.83 & 5.03 & 2.19 \\
\hline 4 & 118.27 & 42.54 & 35.81 & 2.79 & 1.19 & 37.29 & 7.61 & 20.65 & 5.47 & 2.63 \\
\hline 5 & 111.29 & 40.90 & 34.76 & 2.73 & 1.18 & 44.00 & 10.99 & 24.91 & 3.57 & 2.95 \\
\hline 6 & 118.69 & 41.89 & 35.39 & 2.84 & 1.18 & 52.58 & 9.59 & 18.64 & 4.62 & 3.02 \\
\hline 7 & 131.62 & 47.35 & 35.61 & 2.79 & 1.33 & 66.99 & 13.39 & 20.82 & 5.80 & 3.41 \\
\hline 8 & 117.57 & 43.33 & 37.13 & 2.73 & 1.16 & 58.25 & 13.71 & 25.97 & 5.07 & 3.22 \\
\hline 9 & 127.64 & 40.77 & 34.29 & 3.13 & 1.19 & 53.11 & 13.57 & 26.29 & 4.47 & 2.98 \\
\hline 10 & 113.66 & 44.09 & 35.92 & 2.58 & 1.24 & 63.81 & 16.18 & 25.60 & 4.30 & 3.17 \\
\hline 11 & 147.48 & 47.44 & 36.69 & 3.09 & 1.29 & 81.29 & 16.31 & 20.63 & 5.75 & 3.61 \\
\hline 12 & 158.18 & 48.54 & 39.25 & 3.26 & 1.26 & 93.75 & 19.96 & 21.35 & 6.20 & 3.61 \\
\hline 13 & 112.28 & 48.54 & 33.95 & 2.31 & 1.46 & 58.19 & 12.96 & 22.35 & 4.33 & 2.80 \\
\hline 14 & 99.59 & 41.31 & 32.61 & 2.40 & 1.28 & 45.33 & 10.95 & 24.18 & 3.93 & 2.77 \\
\hline 15 & 149.27 & 47.98 & 37.20 & 3.12 & 1.31 & 78.67 & 15.83 & 20.87 & 6.30 & 4.73 \\
\hline 16 & 128.26 & 43.01 & 34.35 & 3.00 & 1.25 & 62.74 & 12.13 & 20.19 & 6.23 & 3.16 \\
\hline 17 & 133.94 & 47.87 & 33.66 & 2.80 & 1.42 & 63.95 & 14.23 & 23.13 & 4.40 & 3.45 \\
\hline 18 & 130.80 & 44.36 & 33.02 & 2.95 & 1.35 & 64.04 & 14.58 & 22.97 & 5.27 & 2.76 \\
\hline 19 & 134.28 & 43.71 & 35.26 & 3.07 & 1.24 & 65.59 & 11.20 & 17.43 & 7.17 & 2.49 \\
\hline 20 & 118.28 & 39.88 & 34.29 & 2.96 & 1.17 & 49.27 & 10.96 & 22.69 & 5.37 & 3.39 \\
\hline 21 & 122.73 & 42.44 & 32.31 & 2.90 & 1.32 & 52.03 & 10.42 & 20.31 & 6.47 & 3.26 \\
\hline 22 & 114.59 & 44.50 & 36.40 & 2.57 & 1.22 & 52.64 & 13.74 & 27.13 & 4.33 & 3.53 \\
\hline 23 & 144.60 & 45.18 & 36.70 & 3.20 & 1.24 & 78.41 & 18.78 & 24.97 & 5.80 & 4.09 \\
\hline 24 & 136.58 & 48.61 & 35.46 & 2.81 & 1.38 & 71.30 & 14.32 & 20.43 & 6.23 & 3.51 \\
\hline 25 & 115.69 & 40.75 & 31.92 & 2.84 & 1.29 & 48.92 & 11.17 & 22.38 & 4.87 & 3.08 \\
\hline Average & 124.89 & 44.05 & 34.93 & 2.84 & 1.27 & 58.26 & 12.64 & 22.07 & 5.17 & 3.11 \\
\hline Minimum & 75.66 & 29.97 & 23.36 & 1.77 & 0.89 & 11.81 & 0.12 & 0.25 & 1.00 & 0.32 \\
\hline Maximum & 220.00 & 72.96 & 50.24 & 4.35 & 2.33 & 191.88 & 39.02 & 48.42 & 15.00 & 8.25 \\
\hline CV (\%) & 20.15 & 14.09 & 11.09 & 15.10 & 14.30 & 44.06 & 47.74 & 31.94 & 47.87 & 33.80 \\
\hline
\end{tabular}

FL: fruit length (mm); FW: fruit width (mm); FT: fruit thickness (mm); LWR: length-to-width fruit ratio (mm); WTR: width-to-thickness fruit ratio (mm); FM: fruit mass (g); PM: pulp mass (g); YIELD: pulp yield (\%; PM/FM); NSF: number of seeds per fruit; M1S: mass of one seed (g).

The average values for fruit thickness and fruit mass (34.93 $\mathrm{mm}$ and $58.26 \mathrm{~g}$, respectively) and the average for number of seeds per fruit (5.17) observed for $H$. stigonocarpa were slightly higher than those observed in populations of the Minas Gerais state (MG) (Botelho 1993). The averages for fruit length and fruit width $(124.89 \mathrm{~mm}$ and $44.05 \mathrm{~mm}$, respectively) observed in this study also exceeded those observed by Botelho (1993). When the same traits for fruits of $H$. stigonocarpa from a population in Brasilândia (MG) were evaluated, the average values for these traits were found to be lower than those obtained in the present study (Botelho et al. 2000). The same was observed in a population sampled in the Goiás state (De-Carvalho et al. 2005). The average values for fruit length and fruit width in this study did not exceed those observed in a population located in Coxim, Mato Grosso do Sul state (MS), which exhibited average values of
$136.23 \mathrm{~mm}$ and $48.32 \mathrm{~mm}$, respectively (Pereira et al. 2011). However, it is noteworthy that the population 12 (Bandeirantes, MS) exceeded both the estimates and exhibited averages for fruit length and fruit width of $158.18 \mathrm{~mm}$ and $48.54 \mathrm{~mm}$, respectively (Table 1).

The average number of seeds per fruit observed in this study was 5.17 (range: 1-15) (Table 1), with the lowest mean (3.30) found in population 1 (Cuiabá, MT) and the highest one (7.17) in population 19 (Bonfinópolis de Minas, MG). Furthermore, the average for this trait in this study was higher than that found in MG populations [3.14 (Botelho 1993) and 4.73 (Botelho et al. 2000)]. In another study, individuals of $H$. stigonocarpa from Coxim (MS) also showed a range of $1-15$, and $42.3 \%$ of the fruits contained three or four seeds (Pereira et al. 2011).

An average mass of one seed of $3.11 \mathrm{~g}(\mathrm{CV}=$ $33.80 \%$ ) was estimated, varying from $1.68 \mathrm{~g}$ in population 2 (General Carneiro, MT) to $4.09 \mathrm{~g}$ in 
population 23 (Araguari, MG) (Table 1). The average value for this trait was close to that estimated for MG populations (3.45 g; Botelho et al. 2000).

Additionally, the present study evaluated other traits that were not previously assessed for H. stigonocarpa (Table 1). For pulp mass and pulp yield, the observed average values were $12.64 \mathrm{~g}$ and $22.07 \%$, respectively (Table 1). Population 3 (Jussara, GO) presented the lowest values for these traits $(6.31 \mathrm{~g}$ and $16.83 \%$, respectively; Table 1). Population 12 (Bandeirantes, MS) had the highest value for pulp mass (19.96 g), while population 22 (Planaltina, GO) showed the highest average pulp yield $(27.13 \%)$. The phenotypic variation observed in these traits may be due to both environmental and genetic factors. This is an unprecedented result for $H$. stigonocarpa and provides fundamental information for its use in food and other commercial industries. Assuming that a portion of the observed variation is due to genetic effects, these traits may be used as criteria for the species' breeding, aiming at the selection of fruits with higher pulp yield (Boaventura-Novaes et al. 2018a).

For traits related to fruit shape, the average of the length-to-width fruit ratio and width-to-thickness fruit ratio were found to be $2.84(\mathrm{CV}=15.10 \%)$ and $1.27(\mathrm{CV}=14.30 \%)$, respectively. These values indicate a low phenotypic variation for these traits (Table 1). Although low coefficient of variation values were observed for these traits, there is a significant diversity in fruit shape for H. stigonocarpa (long and flat, small and cylindrical, rectilinear, and curved) (Figure 2). Thus, it is recommended that other biometric traits should be taken into account for adequately describing the variability observed for fruit shape in this species.

All the evaluated traits showed a significant phenotypic variation at hierarchical levels, corresponding to mother trees within the populations $\left(P_{M / S}\right)$ and among populations $\left(P_{S}\right)$, and high levels of phenotypic variation were detected both for the mother trees and populations (Table 2). The proportion of the total variance explained by the differences among mother trees within populations was $66.0 \%$ for width-to-thickness fruit ratio. The lowest proportion was observed for fruit mass, with differences among mother trees corresponding to $23.0 \%$ of the total variance (Table 2 ). The proportion of the total variance explained by the differences among populations was only $8.0 \%$ for width-tothickness fruit ratio, while fruit mass and lengthto-width fruit ratio showed the greatest variability among populations ( $28.0 \%$ each). These results are relevant to support future $H$. stigonocarpa breeding programs, as wide phenotypic variations, such as those found in the present study, may guide fruit selection criteria based on the evaluated traits, aiming at the establishment of germplasm collections, as well as in situ conservation of the species (Boaventura-

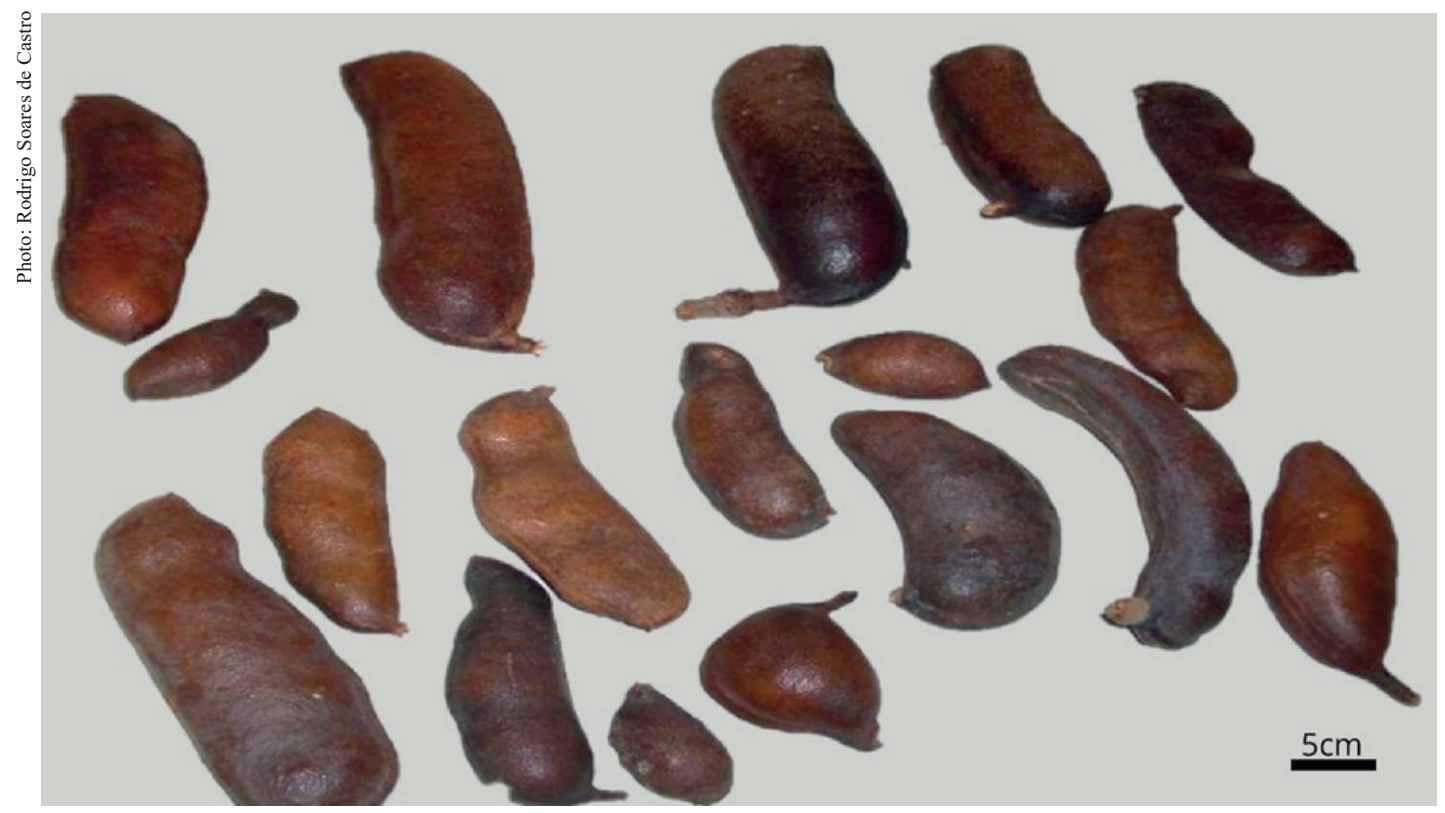

Figure 2. Phenotypic variability in fruit shape observed in 25 populations of Hymenaea stigonocarpa present in the Brazilian Savanna. 
Table 2. Summary of analysis of variance and proportion of components of variation for fruit and seed phenotypic traits of 25 natural populations of Hymenaea stigonocarpa in the Brazilian Savanna.

\begin{tabular}{lrcccccccccc}
\hline \multirow{2}{*}{ Source of variation } & \multirow{2}{*}{ DF } & \multicolumn{10}{c}{ Mean Square } \\
\cline { 2 - 12 } & & \multicolumn{1}{c}{ FL } & FW & FT & LWR & WTR & FM & PM & YIELD & NSF & M1S \\
\hline Populations & 24 & $6,295.4^{* * *}$ & $253.36^{* *}$ & $91.50^{* *}$ & $1.88^{* *}$ & $0.20^{* *}$ & $6,640.6^{* *}$ & $363.15^{* *}$ & $288.51^{* *}$ & $28.50^{* *}$ & $11.52^{* *}$ \\
Plant/Population & 125 & $1,109.9^{* *}$ & $101.57^{* *}$ & $41.98^{* *}$ & $0.35^{* *}$ & $0.12^{* *}$ & $1,081.4^{* *}$ & $70.01^{* *}$ & $129.54^{* *}$ & $12.23^{* *}$ & $2.44^{* *}$ \\
Fruit or seed/Plant & 592 & 303.3 & 16.47 & 6.21 & 0.08 & 0.01 & 327.1 & 17.63 & 30.72 & 3.92 & 0.40 \\
$\mathrm{P}_{\mathrm{S}}(\%)$ & & 0.27 & 0.13 & 0.11 & 0.28 & 0.08 & 0.28 & 0.26 & 0.10 & 0.09 & 0.27 \\
$\mathrm{P}_{\mathrm{M} / \mathrm{S}}(\%)$ & & 0.25 & 0.44 & 0.48 & 0.30 & 0.66 & 0.23 & 0.28 & 0.36 & 0.27 & 0.37 \\
$\mathrm{P}_{\mathrm{NM}}(\%)$ & & 0.47 & 0.42 & 0.41 & 0.43 & 0.26 & 0.49 & 0.46 & 0.55 & 0.64 & 0.36 \\
$\mathrm{P}_{\mathrm{ST}}$ & 0.35 & 0.13 & 0.10 & 0.32 & 0.06 & 0.38 & 0.32 & 0.12 & 0.14 & 0.27 \\
$\mathrm{P}_{\text {ST2 }}$ & & 0.33 & 0.16 & 0.12 & 0.25 & 0.09 & 0.37 & 0.33 & 0.12 & 0.10 & 0.20 \\
\hline
\end{tabular}

FL: fruit length $(\mathrm{mm})$; FW: fruit width $(\mathrm{mm})$; FT: fruit thickness $(\mathrm{mm})$; LWR: length-to-width fruit ratio (mm); WTR: width-to-thickness fruit ratio (mm); FM: fruit mass (g); PM: pulp mass (g); YIELD: pulp yield (\%; PM/FM); NSF: number of seeds per fruit; M1S: mass of one seed (g). **, * Significant at $1 \%$ and $5 \%$ of probability, respectively, by the $F$-test; $P_{S}, P_{M S}$ and $P_{N M}$ : proportion of the total variance due to variation among populations, among mother plants within populations and among fruits or seeds within mother plants, respectively; $P_{S T}$ and $P_{S T 2}$ : phenotypic divergence among populations with and without the $H$. stigonocarpa var. brevipetiolata botanical variety, respectively.

Novaes et al. 2018a). Thus, these results support collection strategies within and among populations for the selection of traits of interest for the species' breeding.

The population phenotypic structure, estimated by $P_{S T}$, indicates the proportion of variance for fruit and seed traits that is due to phenotypic divergences among populations. The lowest phenotypic variability was detected for width-to-thickness fruit ratio, where the divergence among populations explained only $6.0 \%$ of the total variance, whereas the largest one was observed for fruit mass, that explained $38.0 \%$ of the total variance (Table 2 ). As fruits were collected from a large area, the phenotypic variability encompasses the environmental component and considers the various environmental conditions of collection sites, such as degree of anthropization, soil, climate, plant age and others (Ganga et al. 2010).

The $P_{S T}$ index is analogous to the $Q_{S T}$ parameter, where only the additive genetic variance is considered, and also to the $F_{S T}$ parameter, which is estimated from neutral molecular markers that are theoretically not influenced by natural selection (Pujol et al. 2008, Leinonen et al. 2013). The components of genetic variance in the $P_{S T}$ estimation encompass the environmental component in such a way that the divergence found among populations may be due to phenotypic plasticity caused by environmental effects, and not necessarily by evolutionary forces, such as genetic drift and natural selection (Leinonen et al. 2013). However, as it is difficult to carry out experiments with adequate environmental control for the possible estimation of additive or inheritable genetic components, the $P_{S T}$ can provide clues on how the population is structured. In addition, it can generate hypotheses on the traits and populations that would be influenced by natural selection, and these traits can be evaluated in future studies (Leinonen et al. 2008, Pujol 2008). Data from microsatellite markers, obtained from populations overlaid on the sampling area of this study, indicated the existence of high and significant interpopulation genetic differentiation in H. stigonocarpa due to genetic drift (Braga et al. 2019, Gonçalves et al. 2019). The quantitative approach evaluated here demonstrates that phenotypic variability is more relevant at a local level than among populations, as evolutionary forces behave in different ways at different hierarchical levels.

The association analysis between phenotypic traits indicated positive and significant correlations, especially between fruit mass and fruit length, fruit width, pulp mass, number of seeds and mass of one seed (Table 3). Positive and significant correlations were also observed between fruit length and all other traits, except for pulp yield, to which a negative correlation was observed. The positive correlation among pulp mass, fruit length and fruit mass is interesting from the viewpoint of the selection of superior mother trees, because pulp mass is difficult to evaluate in the field. The pulp yield showed low and non-significant correlations with most the other 
Table 3. Correlations between phenotypic variables for fruits and seeds of 25 populations of Hymenaea stigonocarpa using average values of each mother tree.

\begin{tabular}{|c|c|c|c|c|c|c|c|c|c|}
\hline & FW & FT & LWR & WTR & FM & PM & YIELD & $\mathrm{NSF}$ & M1S \\
\hline FL & $0.62 * *$ & $0.32 * *$ & $0.70 * *$ & $0.34 * *$ & $0.85 * *$ & $0.58 * *$ & $-0.25 * *$ & $0.62 * *$ & $0.54 * *$ \\
\hline FW & - & $0.34 * *$ & $-0.11^{\mathrm{ns}}$ & $0.69 * *$ & $0.71 * *$ & $0.53 * *$ & $0.14^{\mathrm{ns}}$ & $0.28 * *$ & $0.44 * *$ \\
\hline FT & - & - & $0.07^{\mathrm{ns}}$ & $0.43^{* *}$ & $0.51 * *$ & $0.53 * *$ & $0.16^{\mathrm{ns}}$ & $0.22 * *$ & $0.36^{* *}$ \\
\hline LWR & - & - & - & $-0.17 *$ & $0.41 * *$ & $0.23 * *$ & $-0.20 *$ & $0.53 * *$ & $0.27 * *$ \\
\hline WTR & - & - & - & - & $0.29 * *$ & $0.10^{\mathrm{ns}}$ & $-0.25 * *$ & $0.09^{\mathrm{ns}}$ & $0.14^{\mathrm{ns}}$ \\
\hline FM & - & - & - & - & - & $0.78 * *$ & $0.12^{\mathrm{ns}}$ & $0.60 * *$ & $0.61 * *$ \\
\hline PM & - & - & - & - & - & - & $0.50 * *$ & $0.26^{* *}$ & $0.46^{* *}$ \\
\hline YIELD & - & - & - & - & - & - & - & $0.40 * *$ & $-0.08^{\text {ns }}$ \\
\hline M1S & - & - & - & - & - & - & - & - & $0.16^{\mathrm{ns}}$ \\
\hline
\end{tabular}

FL: fruit length (mm); FW: fruit width (mm); FT: fruit thickness (mm); LWR: length-to-width fruit ratio (mm); WTR: width-to-thickness fruit ratio (mm); FM: fruit mass (g); PM: pulp mass (g); YIELD: pulp yield (\%; PM/FM); NSF: number of seeds per fruit; M1S: mass of one seed (g). **, $*$ Significant at $1 \%$ and $5 \%$ of probability, respectively, by the $F$-test.

traits, except for fruit length, width-to-thickness fruit ratio, length-to-width fruit ratio and number of seeds, to which the correlations were negative and significant (Table 3). The negative correlation between yield and number of seeds per fruit was expected, as a higher number of seeds results in a lower amount of pulp in the fruit.

A positive and significant correlation was observed only between pulp yield and pulp mass, which was expected because of the mathematical relation between these variables. It is worth noting that several fruits that seemed to be healthy on the outside were found to have deteriorated pulp when open, due to damage by pests or diseases. The correlation coefficients found in this study indicate that the collection of larger and heavier fruits would be more productive if the aim is to collect fruit pulp. For fruit pulp collection, the data suggest that the selection of a certain trait, such as fruit mass, would affect other traits, such as fruit length and pulp mass, in order to support the domestication process and the species' breeding.

The characterization of fruit and seed variables showed that $H$. stigonocarpa var. brevipetiolata has a smaller size and fruit mass, when compared to other botanical varieties. The $P_{S T}$ estimates, when calculated disregarding the populations of $H$. stigonocarpa var. brevipetiolata, had their values changed $\left(P_{S T 2}\right.$; see Table 2$)$. The fruit length, fruit mass, length-to-width ratio, number of seeds and mass of one seed showed lower $P_{S T}$ values after this variety was excluded from the analysis. This result suggests that the phenotypic variation in these traits may be affected by the taxonomic component, as observed in botanical varieties of Hancornia speciosa
Gomes (mangabeira), another fruit species from the Brazilian Savanna (Chaves et al. 2020).

The botanical variety $H$. stigonocarpa var. brevipetiolata showed significantly lower values than the other varieties for six of the 10 evaluated traits: fruit length, fruit mass, length-to-width ratio, pulp mass, number of seeds and mass of one seed, meaning smaller fruits and smaller and fewer seeds (data not shown). At the taxonomic level, this information is very important, as it reinforces the evidence that H. stigonocarpa var. brevipetiolata must be classified as a different species of $H$. stigonocarpa based on molecular data (Braga et al. 2019).

\section{CONCLUSIONS}

1. There is a high phenotypic variation for fruit and seed traits among and within populations of Hymenaea stigonocarpa, with a predominant intrapopulation variation;

2. Pulp mass, the most import commercial trait, is positively correlated with fruit size traits (fruit length, fruit width, fruit thickness and fruit mass), what facilitates the selection of superior plants in the field;

3. Populations 12 (Bandeirantes, MS), 23 (Araguari, MG), 11 (Pedro Gomes, MS), 10 (Poxoréu, MT) and 15 (Aporé, GO), in this order, are indicated as the most promising for seed collection, based on fruit pulp mass;

4. A greater quantitative phenotypic differentiation among the populations was observed for fruit length, fruit mass, pulp mass and mass of one seed, especially when $H$. stigonocarpa var. brevipetiolata was included in the analysis. 


\section{ACKNOWLEDGMENTS}

This research was supported by the Núcleo de Excelência em Recursos Genéticos Vegetais do Cerrado (Cergen) (PRONEX/FAPEG/CNPq 07-2012) and Conselho Nacional de Desenvolvimento Científico e Tecnológico (CNPq) (Universal project 447754/2014-9); L. J. Chaves and M. P. C. Telles have been continuously supported by productivity grants from CNPq; A. R. Gonçalves and R. S. Braga-Ferreira were supported by a fellowship from the Coordenação de Aperfeiçoamento de Pessoal de Nível Superior (Capes) and CNPq. Our current research in Genetics and Genomics is developed in the context of the Instituto Nacional de Ciência \& Tecnologia em Ecologia, Evolução e Conservação da Biodiversidade, supported by MCTIC/CNPq (proc. 465610/2014-5) and Fundação de Amparo à Pesquisa do Estado de Goiás (FAPEG), which we gratefully acknowledge.

\section{REFERENCES}

ALBERTO, F. J.; AITKEN, S. N.; ALÍA, R.; GONZÁLEZMARTÍNEZ, S. C.; HÄNNINEN, H.; KREMER, A.; LEFÈVRE, F.; LENORMAND, T.; YEAMAN, S.; WHETTEN, R.; SAVOLAINEN, O. Potential for evolutionary responses to climate change-evidence from tree populations. Global Change Biology, v. 19, n. 6, p. 1645-1661, 2013.

ALMEIDA, S. P. D.; PROENÇA, C. E. B.; SANO, S. M.; RIBEIRO, J. F. Cerrado: espécies vegetais úteis. Planaltina, DF: Embrapa-CPAC, 1998.

BOAVENTURA-NOVAES, C. R. D.; MOTA, E. E. S.; NOVAES, E.; TELLES, M. P. C.; CHAVES, L. J. Structure of the phenotypic variability of fruit and seed traits in natural populations of Eugenia dysenterica DC. (Myrtaceae). Revista Brasileira de Fruticultura, v. 40, n. 3, p. 1-11, 2018a.

BOAVENTURA-NOVAES, C. R. D.; NOVAES, E.; MOTA, E. E. S.; TELLES M. P. C.; BOTELHO, S. A. Características de frutos, sementes e mudas de jatobá do cerrado, Hymenaea stigonocarpa Mart. Ex Hayne de diferentes procedências. Tese (Doutorado em Ciências Florestais) - Universidade Federal do Paraná, Curitiba, 1993.

BOTELHO, S. A.; FERREIRA, R. A.; MALAVASI, M. de M.; DAVIDE, A. C. Aspectos morfológicos de frutos, sementes, plântulas e mudas de jatobá-do-cerrado (Hymenaea stigonocarpa Mart. ex Hayne) - Fabaceae. Revista Brasileira de Sementes, v. 22, n. 1, p. 144-152, 2000.

BRAGA, R. S.; PINTO, R. B.; CHAVES, L. J.; DINIZFILHO, J. A. F.; SOARES, T. N.; COLLEVATTI, R.
G.; TELLES, M. P. C. Hierarchical genetic and spatial structure among varieties and populations of Hymenaea stigonocarpa (Fabaceae) in Brazilian Savannah. Tree Genetics \& Genomes, v. 15, n. 84, p. 1-16, 2019.

CARVALHO, P. E. R. Jatobá-do-cerrado - Hymenaea stigonocarpa. Colombo: Embrapa Florestas, 2007.

CASTRO, R. S. Variação genética quantitativa e estrutura populacional de Hymenaea stigonocarpa (Mart. ex Hayne) no Cerrado. Tese (Doutorado em Genética e Melhoramento de Plantas) - Universidade Federal de Goiás, Goiânia, 2016.

CHAVES, L. J.; GANGA, R. M. D.; GUIMARÃES, R. A.; CALDEIRA, A. J. R. Quantitative and molecular genetic variation among botanical varieties and populations of Hancornia speciosa Gomes (Apocynaceae). Tree Genetics \& Genomes, v. 16, n. 50, p. 1-11, 2020.

COELHO, A. S. G.; CHAVES, L. J. Genetic drift and uniform selection shape evolution of most traits in Eugenia dysenterica DC. (Myrtaceae). Tree Genetics \& Genomes, v. 14, n. 76 , p. 1-14, 2018 b.

DE-CARVALHO, P. S.; MIRANDA, S. do C. de; SANTOS, M. L. dos. Germinação e dados biométricos de Hymenaea stigonocarpa Mart. Ex Hayne (Leguminosae Caesalpinoideae) - jatobá-do-cerrado. Revista Anhanguera, v. 6, n. 1, p. 101-116, 2005.

FRANÇOSO, R. D.; DEXTER, K. G.; MACHADO, R. B.; PENNINGTON, R. T.; PINTO, J. R. R.; BRANDÃO, R. A.; RATTER, J. A. Delimiting floristic biogeographic districts in the Cerrado and assessing their conservation status. Biodiversity Conservation, v. 29, n. 5, p. 14771500, 2020.

GANGA, R. M. D.; FERREIRA, G. A.; CHAVES, L. J.; NAVES, R. V.; NASCIMENTO, J. L. Caracterização de frutos e árvores de populações naturais de Hancornia speciosa Gomes do Cerrado. Revista Brasileira de Fruticultura, v. 32, n. 1, p. 101-113, 2010.

GIBBS, P. E.; OLIVEIRA, P. E.; BIANCHI, M. B. Postzygotic control of selfing in Hymenaea stigonocarpa (Leguminosaea - Caesalpinoideae), a bat-pollinated tree of the Brazilian Cerrados. International Journal of Plant Sciences, v. 160, n. 1, p. 72-78, 1999.

GONÇALVES, A. R.; CHAVES, L. J.; TELLES, M. P. C. Genetic variability and effective population size in Hymenaea stigonocarpa (Fabaceae) germplasm collection: tools for breeding programs and genetic conservation. Genetica, v. 147, n. 5-6, p. 359-368, 2019.

LEINONEN, T.; MCCAIRNS, R. J. S.; O'HARA, R. B.; MERILÄ, J. Qst-Fst comparisions: evolutionary and ecological insights from genomic heterogeneity. Nature Reviews Genetics, v. 14, n. 3, p. 179-190, 2013. 
LEINONEN, T.; O'HARA, R. B.; CANO, J. M.; MERILÄ, J. Comparative studies of quantitative trait and neutral marker divergence: a meta-analysis. Journal of Evolutionary Biology, v. 21, n. 1, p. 1-17, 2008.

MENDONÇA, R. C.; FELFILI, J. M.; WALTER, B. M. T.; SILVA-JÚNIOR, M. C.; REZENDE, A. V.; FILGUEIRAS, T. S.; FAGG, C. W. Flora vascular do bioma Cerrado: checklist com 12.356 espécies. In: SANO, S. M.; ALMEIDA, S. P.; RIBEIRO, J. F. (org.). Cerrado: ecologia e flora. Brasília, DF: Embrapa Informação Tecnológica, 2008. p. 422-442.

MITTERMEIER, R. A.; TURNER, W. R.; LARSEN, F. W.; BROOKS, T. M.; GASCON, C. Global biodiversity conservation: the critical role of hotspots. In: ZACHOS, F.; HABEL, J. (ed.). Biodiversity hotspots. Berlin: Springer, 2011. p. 3-22.

NEALE, D. B.; KREMER, A. Forest tree genomics: growing resources and applications. Nature Reviews Genetics, v. 12, n. 2, p. 111-122, 2011.

PEREIRA, S. R.; GIRALDELLI, G. R.; LAURA, V. A.; SOUZA, A. L. T. de. Tamanho de frutos e de sementes e sua influência na germinação de jatobá-do-cerrado (Hymenaea stigonocarpa var. stigonocarpa Mart. ex Hayne, Leguminosae - Caesalpinoideae). Revista Brasileira de Sementes, v. 33, n. 1, p. 141-148, 2011.

PESTANA, L. T. C. Estudo taxonômico de Hymenaea L.: complexo H. courbaril, H. martiana e H. stigonocarpa (Fabaceae: Caesalpinioideae: Detarieae). Dissertação (Mestrado em Biologia Vegetal) - Universidade Federal de Mato Grosso do Sul, Campo Grande, 2010.

PINTO, R. B.; TOZZI, A. M. G. A.; MANSANO, V. F. Hymenaea in flora do Brasil 2020 em construção. 2020. Available at: http://reflora.jbrj.gov.br/reflora/floradobrasil/ FB83206. Access on: 29 Dec. 2020.

PUJOL, B.; WILSON, A. J.; ROSS, R. I. C.; PANNELL, J. R. Are Qst-Fst comparisions for natural populations meaningful? Molecular Ecology, v. 17, n. 22, p. 47824785, 2008.

SIMON, M. F.; PENNINGTON, T. Evidence for adaptation to fire regimes in the tropical Savannas of the Brazilian Cerrado. International Journal of Plant Sciences, v. 173, n. 6, p. 711-723, 2012. 